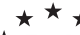

$\star$ Polltyki Europejskie.

$\star$ Finanse i Marketing

$\star \star \star \quad 19(68) 2018$

DOI 10.22630/PEFIM.2018.19.68.12

Grażyna Michalczuk

Uniwersytet w Bialymstoku

Urszula Konarzewska

Uniwersytet w Bialymstoku

\title{
Komunikowanie działań CSR w procesie społecznie odpowiedzialnego inwestowania
}

\section{COMMUNICATION OF CSR ACRIVITIES IN THE PROCESS OF SOCIALLY RESPONSIBLE INVESTING}

Efektywność bieżacej dziatalności przedsiębiorstwa oraz realizacja jego celów rozwojowych wiaże się nierozerwalnie z pozyskiwaniem odpowiednich zasobów kapitatu. Znalezienie inwestorów w coraz większym stopniu uwarunkowane jest nie tylko budowaniem wizerunku firmy wiarygodnej finansowo. Wielu inwestorów w procesie wyboru portfela tradycyjne kryteria finansowe uzupetnia również zasadami społecznej odpowiedzialności biznesu. Rozwój koncepcji społecznie odpowiedzialnego inwestowania wywotuje zainteresowanie zwiększonq aktywnościq przedsiębiorstw $w$ zakresie dostarczania informacji nie tylko $w$ perspektywie finansowej, ale też spolecznej iśrodowiskowej.

Celem artykułu jest przedstawienie znaczenia komunikacji działań CSR $w$ procesie społecznie odpowiedzialnego inwestowania. Punktem wyjścia do realizacji tak sformulowanego celu byto przedstawienie teoretycznych podstaw koncepcji społecznie odpowiedzialnego inwestowania, jak $i$ zagadnień zwiazanych z komunikowaniem informacji z zakresu CSR, mogacych $w$ istotny sposób wspierać ten proces. W dalszej części artykulu skoncentrowano się na analizie podejścia do komunikowania działań społecznie odpowiedzialnych przez spótki wchodzqce $w$ skład indeksu RESPECT.

Badania wykazały, że spótki Indeksu RESPECT sq świadome znaczenia ujawniania informacji z obszaru spotecznej odpowiedzialności biznesu. Większość z nich nie ogranicza się do komunikowania kwestii ekonomicznych, społecznych i środowiskowych $w$ sprawozdaniach z działalności, ale publikuje dodatkowo odrębne raporty CSR, badź też raporty zintegrowane, które za pomoca jednego dokumentu prezentuja zarówno finansowe, jak i niefinansowe aspekty prowadzonej dziatalności gospodarczej.

Słowa kluczowe: społeczna odpowiedzialność biznesu, społecznie odpowiedzialne inwestowanie, komunikowanie działań społecznie odpowiedzialnych

\section{Wstęp}

Rosnące zainteresowanie społeczną odpowiedzialnością biznesu i jej przenikanie do wszystkich aspektów życia gospodarczego, wywarło wpływ na funkcjonowanie rynków finansowych. Na gruncie koncepcji CSR rozwinęło się pojęcie społecznie odpowiedzialnego inwestowania, które odnosi się do podejmowania decyzji inwestycyjnych nie tylko w oparciu o finansowe rezultaty danego podmiotu, ale również te dotyczące aspektów społecznych, czy też środowiskowych. Coraz większą atrakcyjnością z punktu widzenia 
kapitałodawców charakteryzują się te podmioty, które osiągają nie tylko dobre wyniki finansowe, ale odznaczają się jednocześnie przejrzystością działania oraz uczciwie podchodzą do budowania własnego wizerunku oraz kształtowania relacji z najbliższym otoczeniem ${ }^{1}$. Dla wielu inwestorów, to właśnie wiarygodność społeczna jest podstawą oceny prowadzonej działalności gospodarczej danego przedsiębiorstwa, determinującą również perspektywę jego wiarygodności finansowej².

Wraz z rosnąca popularnością inwestycji społecznie odpowiedzialnych na znaczeniu nabiera jakość oraz kompletność generowanych informacji nie tylko w perspektywie finansowej, ale też społecznej i środowiskowej. Coraz częściej wyniki finansowe (mające największą wartość dla akcjonariuszy) szacowane są w kontekście społecznej odpowiedzialności, która jest koncepcją umożliwiającą budowanie relacji z wieloma interesariuszami. Zauważalną kwestią pozostaje jednak zróżnicowanie zarówno zakresu prezentowanych danych, jak również kanałów komunikowania, które wykorzystywane mogą być do upubliczniania tego typu informacji.

Celem artykułu jest przedstawienie znaczenia komunikowania działań CSR w procesie społecznie odpowiedzialnego inwestowania. Punktem wyjścia do realizacji tak sformułowanego celu było omówienie teoretycznych podstaw koncepcji społecznie odpowiedzialnego inwestowania, jak i zagadnień związanych z komunikowaniem informacji z zakresu CSR, mogących w istotny sposób wspierać ten proces. W dalszej części artykułu skoncentrowano się na podejściu do komunikowania działań społecznie odpowiedzialnych przez spółki wchodzące w skład indeksu RESPECT.

\section{Społecznie odpowiedzialne inwestowanie (SRI)}

Współcześnie przedsiębiorstwa funkcjonują w otoczeniu, które legitymizuje ich działalność ${ }^{3}$. Otoczenie to, $\mathrm{z}$ jednej strony może stwarzać możliwości dla długofalowego rozwoju i osiagania określonych celów strategicznych, z drugiej natomiast może stanowić zagrożenie dla powodzenia realizowanych przedsięwzięć rynkowych. W budowaniu relacji z otoczeniem istotne znaczenie odgrywa uzyskanie akceptacji dla realizowanych przedsięwzięć rynkowych.

Coraz więcej podmiotów swoje relacje z otoczeniem buduje w oparciu o koncepcję społecznej odpowiedzialności biznesu (Corporate Social Responsibility - CSR). Polega ona na uwzględnianiu w strategii przedsiębiorstwa interesów społecznych, kwestii środowiskowych oraz relacji z szeroko rozumianym otoczeniem przedsiębiorstwa (różnymi grupami interesu). Istotne znaczenie ma fakt, iż praktyczna implementacja CSR nie może opierać się jedynie na składaniu deklaracji w tym zakresie. Musi wiązać się z wysoką świadomością społecznej odpowiedzialności oraz długofalowym działaniem na

\footnotetext{
${ }^{1}$ A. Mazurczak, Raportowanie społecznej odpowiedzialności biznesu jako nowy element raportowania biznesowego [w:] B. Micherda (red.), Kierunki ewolucji sprawozdawczości i rewizji finansowej, Wydawnictwo Difin, Warszawa 2012, s. 93.

${ }^{2}$ B. Rok, Odpowiedzialny biznes $w$ nieodpowiedzialnym świecie, Akademia Rozwoju Filantropii w Polsce Forum Odpowiedzialnego Biznesu, Warszawa 2004, s. 54.

${ }^{3}$ I. Mendryk, Budowanie relacji z otoczeniem jako kompetencja organizacji, „Annales Universitatis Mariae Curie-Sklodowska. Sectio H. Oeconomia”, 2008, Vol. XLII, 10, s. 143.
} 
rzecz rozwiązywania istotnych problemów społecznych, które mogą przynieść korzyści zarówno poszczególnym grupom interesariuszy, jak i przedsiębiorstwu ${ }^{4}$.

Zasadność realizacji w praktyce spółek koncepcji społecznej odpowiedzialności dostrzegają inwestorzy, którzy chcą inwestować nie tylko z zyskiem, ale też odpowiedzialnie. Oznacza to świadome inwestowanie w spółki funkcjonujące w oparciu o zasadę CSR. Efektem jest rozwój nowej formy inwestowania jaką jest społecznie odpowiedzialne inwestowanie (Socially Responsible Investing - SRI). W literaturze można spotkać różne podejścia do definiowania SRI, co ilustruje tabela 1.

Tabela 1. Podejścia do definiowania społecznie odpowiedzialnego inwestowania (SRI)

\begin{tabular}{|l|l|}
\hline Autor/Źródlo & Definicja \\
\hline P. Kinder & $\begin{array}{l}\text { Dotyczy ono wcielania kryteriów społecznych lub etycznych w proces } \\
\text { podejmowania decyzji inwestycyjnych }\end{array}$ \\
\hline $\begin{array}{l}\text { Raport Światowego } \\
\text { Forum Ekonomicznego }\end{array}$ & $\begin{array}{l}\text { To inwestowanie w sposób biorący pod uwagę wpływ inwestycji na szeroko } \\
\text { rozumiane społeczeństwo oraz środowisko naturalne, zarówno dzisiaj, jak i } \\
\text { w przyszłości }\end{array}$ \\
\hline $\begin{array}{l}\text { Europejska organizacja } \\
\text { ds. Zrównoważonego } \\
\text { Inwestowania }\end{array}$ & $\begin{array}{l}\text { To ogólny termin obejmujący etyczne inwestycje, odpowiedzialne inwesty- } \\
\text { cje, inwestycje zrównoważone oraz wszelkie inne procesy inwestycyjne, } \\
\text { które łączą cele finansowe inwestorów z ich troską o zagadnienia środowi- } \\
\text { skowe, społeczne i zarządzania. }\end{array}$ \\
\hline
\end{tabular}

Źródło: Opracowanie własne na podstawie: T. Jedynak, Kontrowersje wokól efektywności inwestycji społecznie odpowiedzialnych, ,Zeszyty Naukowe Polskiego Towarzystwa Ekonomicznego”, 2011, nr 11, s. 239.

Istotą SRI jest opieranie decyzji finansowych inwestorów nie tylko na parametrach finansowych (m.in. zysku) spółek, ale też ich współobecności w społeczeństwie. Budowanie portfela inwestycyjnego odbywa się poprzez dobór spółek spełniających standardy społecznej odpowiedzialności. Celem stosowania SRI jest więc z jednej strony maksymalizowanie zysku przy najmniejszym możliwym ryzyku, z drugiej - wkomponowanie w proces inwestycyjny aspektów o charakterze społeczno-etycznym, ekologicznym i środowiskowym ${ }^{5}$.

Inwestowanie społeczne znajduje coraz większe zainteresowanie w Polsce. Niewątpliwie wpływ na to miały działania Giełdy Papierów Wartościowych w Warszawie, która w 2009 roku zapoczątkowała Indeks RESPECT ${ }^{6}$, który służy do mierzenia wartości spółek najbardziej odpowiedzialnych społecznie. Głównym celem projektu jest wyłonienie spółek giełdowych zarządzanych w sposób odpowiedzialny oraz akcentowanie ich atrakcyjności inwestycyjnej ${ }^{7}$.

Indeks podlega cyklicznemu badaniu i weryfikacji, co pozwala na utrzymanie ,wysokiego poziomu oraz na zapewnienie, że są to spółki działające zgodnie

\footnotetext{
${ }^{4}$ M. Żychlewicz, Spoleczna odpowiedzialność biznesu jako strategia prowadzenia działalności polskich przedsiębiorstw, „Współczesne problemy ekonomiczne”, 2015, nr 11, s. 282-284.

${ }_{5}^{5}$ T. Jedynak, Rozwój koncepcji inwestowania spolecznie odpowiedzialnego w Polsce i na świecie, „Zeszyty Naukowe Uniwersytetu Ekonomicznego w Krakowie", 2011, nr 875, s. 18.

${ }^{6}$ Był to pierwszy indeks spółek odpowiedzialnych na obszarze Europy Środkowo - Wschodniej i objął 16 spółek notowanych na rynku głównym GPW (z wyłączeniem spółek zagranicznych oraz duallistingowanych), które wykazały się ponadprzeciętnym zaangażowaniem w zagadnienia CSR. Na koniec 2016 roku w skład indeksu weszło 25 spółek z różnych sektorów.

${ }^{7}$ RESPECT Index, Opis projektu, http://www.odpowiedzialni.gpw.pl/opis_projektu [data dostępu: 01.10.2017].
} 
z najlepszymi standardami zarządzania w zakresie corporate governance, ładu informacyjnego i relacji inwestorskich oraz na płaszczyźnie ekologicznej, społecznej i stosunków pracowniczych ${ }^{8}$.

Aktualnie w indeksie RESPECT znajdują się 24 spółki. Różnicuje je nie tylko długość notowań na GPW, ale też przynależność sektorowa. Wśród spółek indeksu dominują banki - 5 spółek. Znaczący jest również udział przedsiębiorstw $\mathrm{z}$ takich sektorów, jak: energia - 4 spółki, budownictwo - 3 spółki oraz paliwa i gaz - 3 spółki ${ }^{10}$. Są to branże gospodarki, które z jednej strony wywierają istotny wpływ na bliższe oraz dalsze otoczenie funkcjonowania, z drugiej natomiast odznaczać muszą się dużą przejrzystością realizowanych przedsięwzięć.

\section{Komunikowanie społecznej odpowiedzialności biznesu w praktyce spółek indeksu RESPECT}

Idea społecznie odpowiedzialnego inwestowania skupia wokół siebie inwestorów zainteresowanych nie tylko długoterminową maksymalizacją zysków, lecz także szeroko pojętą odpowiedzialnością, przejawiającą się między innymi troską o drugiego człowieka oraz o środowisko naturalne ${ }^{11}$. Inwestorzy opierający swoją strategię inwestowania na zasadach społecznie odpowiedzialnego inwestowania zainteresowani są zwiększoną otwartością informacyjną spółek. Wiąże się ona z dostarczaniem informacji, które dadzą podstawę obiektywnej oceny, czy w rzeczywistości i w jakim stopniu podmiot respektuje zasady społecznej odpowiedzialności biznesu ${ }^{12}$.

Komunikowanie społecznej odpowiedzialności biznesu należy do zagadnień stosunkowo nowych. Wynika to $\mathrm{z}$ faktu, że dopiero na przestrzeni ostatnich lat nastąpił znaczący wzrost zainteresowania nie tylko finansowymi, ale także społecznymi i środowiskowymi aspektami prowadzonej działalności. Często wykorzystywanym sposobem informowania otoczenia o społecznej odpowiedzialności biznesu są komunikaty umieszczane na stronach internetowych przedsiębiorstw. W zakładkach dotyczących zaangażowania społecznego lub odpowiedzialnego biznesu zamieszczane są informacje na temat programów społecznych, akcji charytatywnych, oraz współpracy firmy z partnerami społecznymi ${ }^{13}$.

Z punktu widzenia realizacji koncepcji społecznie odpowiedzialnego inwestowania są to informacje niewystarczające. Coraz częściej znajdują one swoje miejsce w systemie sprawozdawczości jednostek gospodarczych. Takim źródłem jest między

\footnotetext{
${ }^{8}$ Tamże.

9 Zmiana liczby spółek wchodzących do struktury indeksu w porównaniu do pierwotnego składu dziesiątej edycji projektu, ogłoszonego w grudniu 2016 roku spowodowana została decyzją Zarządu Giełdy Papierów Wartościowych w Warszawie o zawieszeniu obrotu akcjami spółki Pelion S.A.

${ }^{10}$ GPW, Lista spótek, https://www.gpw.pl/spolki [data dostępu: 09.10.2017].

${ }^{11}$ J. Ostaszewski (red.), Finanse, Wydawnictwo Difin, Warszawa 2013, s. 567-568.

${ }^{12}$ T. Szot- Gabryś, Spolecznie odpowiedzialne inwestowanie a spolecznie odpowiedzialne inwestycje [w:] J. Ostaszewski (red.), O nowy ład finansowy w Polsce. Rekomendacje dla animatorów życia gospodarczego, Szkoła Główna Handlowa w Warszawie, Warszawa 2015, s. 315.

${ }^{13}$ A. Rudnicka, Komunikowanie o społecznej odpowiedzialności między przedsiębiorstwem a interesariuszami [w:] Z. Pisz, M. Rojek-Nowosielska (red.), Społeczna odpowiedzialność organizacji. Metodyka, narzędzia, ocena, Wydawnictwo Uniwersytetu Ekonomicznego we Wrocławiu, Wrocław 2011, s. 120.
} 
innymi sprawozdanie z działalności, które zgodnie ze znowelizowaną ustawą o rachunkowości będzie musiało zawierać oświadczenie zawierające minimum informacji niefinansowych ${ }^{14}$, w odniesieniu do kwestii środowiskowych, społecznych i pracowniczych, poszanowania praw człowieka, a także przeciwdziałania korupcji i łapownictwu ${ }^{15}$.

Kluczowym narzędziem komunikowania danych z zakresu CSR w ostatnich latach stają się raporty społeczne. W sposób całościowy przedstawiają one strategię danej jednostki, jej politykę społeczna, a także wyniki w zakresie odpowiedzialności wobec kluczowych grup interesariuszy ${ }^{16}$. Sprawozdania tego typu stanowią odpowiedź na zarzuty kierowane w stronę jednostek, że w prowadzonej przez nie polityce informacyjnej preferowane są interesy ograniczonej grupy podmiotów ${ }^{17}$. Podstawowymi adresatami obligatoryjnej sprawozdawczości są właściciele, potencjalni inwestorzy oraz instytucje finansowe $^{18}$. Natomiast raporty społeczne kierowane są również do innych grup interesariuszy, które zainteresowane są różnymi aspektami funkcjonowania spółki.

Spółki tworzące skład Indeksu RESPECT są świadome znaczenia ujawniania informacji z obszaru społecznej odpowiedzialności biznesu. W związku z tym, że w zakresie raportowania społecznego nie ma wypracowanego jednolitego standardu, wykorzystują one w tym celu różne rodzaje sprawozdań, co ilustruje tabela 2.

Tabela 2. Informacje z zakresu społecznej odpowiedzialności w sprawozdawczości spółek wchodzących w skład indeksu RESPECT

\begin{tabular}{|c|c|c|c|c|c|c|}
\hline Sektor & Nazwa spółki & $\begin{array}{c}\text { CSR w } \\
\text { sprawozda- } \\
\text { niu } \\
\text { z dzialalno- } \\
\text { ści/ } \\
\end{array}$ & $\begin{array}{c}\text { Nazwa raportu z } \\
\text { zakresu spolecznej } \\
\text { odpowiedzialności }\end{array}$ & $\begin{array}{l}\text { Rodzaj } \\
\text { raportu }\end{array}$ & $\begin{array}{c}\text { Za } \\
\text { okres }\end{array}$ & Format \\
\hline \multirow{3}{*}{ Banki } & $\begin{array}{l}\text { ING Bank } \\
\text { Śląski S.A. }\end{array}$ & & $\begin{array}{c}\text { Zintegrowany } \\
\text { Raport Roczny ING } \\
\text { Banku Śląskiego } \\
2016\end{array}$ & $\begin{array}{l}\text { Raport } \\
\text { zinte- } \\
\text { growany }\end{array}$ & $\begin{array}{l}2015- \\
2016\end{array}$ & online \\
\hline & $\begin{array}{c}\text { Bank } \\
\text { Zachodni WBK } \\
\text { S.A. }\end{array}$ & & $\begin{array}{l}\text { Raport Odpowie- } \\
\text { dzialnego Biznesu } \\
2016\end{array}$ & $\begin{array}{c}\text { Raport } \\
\text { CSR }\end{array}$ & 2016 & online \\
\hline & $\begin{array}{c}\text { Bank } \\
\text { Millennium } \\
\text { S.A. }\end{array}$ & & $\begin{array}{c}\text { Raport finansowy i } \\
\text { społeczny za rok } \\
2016\end{array}$ & $\begin{array}{c}\text { Raport } \\
\text { zinte- } \\
\text { growany }\end{array}$ & 2016 & online \\
\hline
\end{tabular}

\footnotetext{
${ }^{14}$ Obowiązek będzie dotyczył wyłącznie dużych jednostek zaufania publicznego, czyli między innymi: banków, zakładów ubezpieczeń, funduszy inwestycyjnych, funduszy emerytalnych, emitentów papierów wartościowych, krajowych instytucji płatniczych oraz instytucji pieniądza elektronicznego. Wymogi odnosić będą się również do grup kapitałowych, w których podmiotem dominującym jest jednostka zaufania publicznego. Podstawę zastosowania przepisów stanowić będą kryteria określające skalę prowadzonej działalności gospodarczej dotyczące liczby zatrudnionych, a także wielkości przychodów netto ze sprzedaży lub sumy aktywów bilansu (Ustawa z dnia 29 września 1994 r. o rachunkowości, Dz. U. 1994 Nr 121 poz. 591, ze zm., art. 49b55.

${ }^{15}$ Ustawa z dnia 29 września 1994 r. o rachunkowości, Dz. U. 1994 Nr 121 poz. 591, ze zm., art. 49b, ust. 2.

${ }^{16}$ B. Rok, Odpowiedzialny biznes..., op. cit., s. 70.

${ }^{17}$ E. Maćkowiak, Polityka rachunkowości a kierunki zmian raportowania $w$ przedsiębiorstwach, „Studia Ekonomiczne", 2014, nr 201, s. 190.

${ }^{18}$ G. Zasuwa, Spoleczna odpowiedzialność jako perspektywiczny obszar w sprawozdawczości przedsiębiorstw [w:] D.A. Mikulska, Polityka rachunkowości jednostki a jakość sprawozdania finansowego. Wybrane aspekty, Wydawnictwo KUL, Lublin 2012, s. 194.
} 


\begin{tabular}{|c|c|c|c|c|c|}
\hline & $\begin{array}{c}\text { Bank } \\
\text { Handlowy w } \\
\text { Warszawie } \\
\text { S.A. } \\
\end{array}$ & - & - & - & - \\
\hline & $\begin{array}{c}\text { Bank } \\
\text { Pekao S.A. }\end{array}$ & - & - & - & - \\
\hline \multirow{4}{*}{ Energia } & PGE S.A. & $\begin{array}{l}\text { Raport zintegrowa- } \\
\text { ny } 2016\end{array}$ & $\begin{array}{l}\text { Raport } \\
\text { zinte- } \\
\text { growany }\end{array}$ & 2016 & online \\
\hline & $\begin{array}{l}\text { Tauron Polska } \\
\text { Energia S.A. }\end{array}$ & $\begin{array}{c}\text { Raport zintegrowa- } \\
\text { ny } 2016\end{array}$ & $\begin{array}{l}\text { Raport } \\
\text { zinte- }\end{array}$ & 2016 & online \\
\hline & Energa S.A. & $\begin{array}{l}\text { Nasza odpowie- } \\
\text { dzialność } 2016\end{array}$ & $\begin{array}{c}\text { Raport } \\
\text { CSR }\end{array}$ & 2016 & PDF \\
\hline & $\begin{array}{c}\text { ZEW } \\
\text { Kogeneracja }\end{array}$ & - & - & - & - \\
\hline \multirow{4}{*}{$\begin{array}{l}\text { Budow- } \\
\text { nictwo }\end{array}$} & \multirow{2}{*}{$\begin{array}{l}\text { Elektrobudowa } \\
\text { S.A. }\end{array}$} & $\begin{array}{l}\text { Społeczna odpowie- } \\
\text { dzialność biznesu } \\
\text { Raport } 2016\end{array}$ & $\begin{array}{c}\text { Raport } \\
\text { CSR }\end{array}$ & 2016 & PDF \\
\hline & & $\begin{array}{c}\text { Global Compact } \\
\text { Raport } 2016 \\
\end{array}$ & $\begin{array}{l}\text { Raport } \\
\text { CSR }\end{array}$ & 2015 & PDF \\
\hline & Budimex S.A. & $\begin{array}{c}\text { Zintegrowany raport } \\
\text { roczny } 2016\end{array}$ & $\begin{array}{c}\text { Raport } \\
\text { zinte- } \\
\text { growany }\end{array}$ & 2016 & PDF \\
\hline & $\begin{array}{l}\text { Trakcja PRKiI } \\
\text { S.A. }\end{array}$ & $\begin{array}{c}\text { Raport społeczny } \\
2015\end{array}$ & $\begin{array}{l}\text { Raport } \\
\text { CSR }\end{array}$ & 2015 & PDF \\
\hline \multirow{3}{*}{$\begin{array}{l}\text { Paliwa i } \\
\text { gaz }\end{array}$} & $\begin{array}{c}\text { Grupa LOTOS } \\
\text { S.A. }\end{array}$ & $\begin{array}{l}\text { Zintegrowany raport } \\
\text { roczny } 2016\end{array}$ & $\begin{array}{l}\text { Raport } \\
\text { zinte- } \\
\text { growany }\end{array}$ & 2016 & online \\
\hline & PGNiG S.A. & $\begin{array}{c}\text { Raport społeczny } \\
\text { GK PGNiG } 2014 \\
\text { Odpowiedzialna } \\
\text { energia }\end{array}$ & $\begin{array}{c}\text { Raport } \\
\text { CSR }\end{array}$ & 2014 & $\begin{array}{l}\text { online } \\
\text { PDF }\end{array}$ \\
\hline & PKN Orlen S.A. & $\begin{array}{c}\text { Raport Zintegrowa- } \\
\text { ny Grupy ORLEN } \\
2016 \\
\end{array}$ & $\begin{array}{c}\text { Raport } \\
\text { zinte- } \\
\text { growany }\end{array}$ & 2016 & $\begin{array}{l}\text { online } \\
\text { PDF }\end{array}$ \\
\hline \multirow{3}{*}{ Chemia } & \multirow[b]{2}{*}{$\begin{array}{l}\text { Grupa Azoty } \\
\text { S.A. }\end{array}$} & $\begin{array}{l}\text { Raport zintegrowa- } \\
\text { ny Grupy Azoty za } \\
\text { rok } 2015\end{array}$ & $\begin{array}{l}\text { Raport } \\
\text { zinte- } \\
\text { growany }\end{array}$ & 2015 & PDF \\
\hline & & $\begin{array}{c}\text { Roczny raport na } \\
\text { temat kwestii śro- } \\
\text { dowiskowych i } \\
\text { społecznych za } 2016 \\
\text { r. }\end{array}$ & $\begin{array}{c}\text { Raport } \\
\text { CSR }\end{array}$ & 2016 & PDF \\
\hline & $\begin{array}{c}\text { PCC Rokita } \\
\text { S.A. }\end{array}$ & - & - & - & - \\
\hline
\end{tabular}

${ }^{19}$ Pewne informacje z zakresu CSR znaleźć można w Raportach z działań społecznych sporządzanych przez Fundację powołaną celu wspierania działań Banku na rzecz ekonomicznej, społecznej, a także środowiskowej odpowiedzialności.

${ }^{20}$ Odniesienia do społecznego zaangażowania spółki ujęte zostały w Raporcie zrównoważonego rozwoju Grupy EDF za lata 2014-2015, w której skład której wchodzi ZEW Kogeneracja S.A. 


\begin{tabular}{|c|c|c|c|c|c|}
\hline \multirow{2}{*}{$\begin{array}{c}\text { Górnic- } \\
\text { two }\end{array}$} & $\begin{array}{l}\text { KGHM Polska } \\
\text { Miedź S.A. }\end{array}$ & $\begin{array}{l}\text { Raport zintegrowa- } \\
\text { ny za } 2016 \text { rok }\end{array}$ & $\begin{array}{l}\text { Raport } \\
\text { zinte- } \\
\text { growany }\end{array}$ & 2016 & online \\
\hline & $\begin{array}{l}\text { Lubelski Wę- } \\
\text { giel Bogdanka } \\
\text { S.A. }\end{array}$ & $\begin{array}{c}\text { Raport zintegrowa- } \\
\text { ny GK LW BOG- } \\
\text { DANKA za } 2016 \\
\text { rok }\end{array}$ & $\begin{array}{l}\text { Raport } \\
\text { zinte- } \\
\text { growany }\end{array}$ & 2016 & PDF \\
\hline $\begin{array}{c}\text { Przemysl } \\
\text { elektro- } \\
\text { maszy- } \\
\text { nowy }\end{array}$ & Apator S.A. & $\begin{array}{l}\text { Raport zrównowa- } \\
\text { żonego rozwoju } \\
2015\end{array}$ & $\begin{array}{l}\text { Raport } \\
\text { CSR }\end{array}$ & 2015 & online \\
\hline $\begin{array}{l}\text { Teleko- } \\
\text { munika- } \\
\text { cja }\end{array}$ & $\begin{array}{c}\text { Orange Polska } \\
\text { S.A. }\end{array}$ & $\begin{array}{l}\text { Orange Polska } \\
\text { Raport Zintegrowa- } \\
\text { ny } 2016\end{array}$ & $\begin{array}{l}\text { Raport } \\
\text { zinte- } \\
\text { growany }\end{array}$ & 2016 & $\begin{array}{l}\text { online } \\
\text { PDF }\end{array}$ \\
\hline $\begin{array}{l}\text { Ubezpie- } \\
\text { czenia }\end{array}$ & PZU S.A. & $\begin{array}{c}\text { Raport społecznej } \\
\text { odpowiedzialności } \\
\text { biznesu PZU S.A. } \\
\text { 2013-2014 }\end{array}$ & $\begin{array}{l}\text { Raport } \\
\text { CSR }\end{array}$ & $\begin{array}{l}2013- \\
2014\end{array}$ & PDF \\
\hline $\begin{array}{l}\text { Rynek } \\
\text { kapita- } \\
\text { lowy }\end{array}$ & $\begin{array}{c}\text { GPW w } \\
\text { Warszawie S.A. }\end{array}$ & - & - & - & - \\
\hline $\begin{array}{l}\text { Wyposa- } \\
\text { żenie } \\
\text { domu }\end{array}$ & $\begin{array}{c}\text { Fabryki Meble } \\
\text { FORTE S.A. }\end{array}$ & - & - & - & - \\
\hline
\end{tabular}

Źródło: Opracowanie własne na podstawie raportów zamieszczonych na stronach internetowych badanych spółek (według stanu na dzień 09.10.2017 r.).

Spółki indeksu różnicuje sposób komunikowania na temat społecznej odpowiedzialności. Wszystkie z nich dołączają informacje z zakresu CSR bezpośrednio do raportów rocznych, bądź też ujawniają je w ramach sprawozdania z działalności, stanowiącego element rocznego raportu przedsiębiorstwa. Informacje te mają jednak różny zakres. W niektórych przypadkach ograniczają się one wyłącznie do opisu wyznawanych wartości, czy też wspieranych akcji charytatywnych i sponsoringowych. Powoduje to, że dają jedynie cząstkowy pogląd na temat społecznego zaangażowania poszczególnych firm oraz skutków prowadzonej przez nie działalności gospodarczej. Dlatego też coraz więcej spółek w celu komunikowania społecznego zaangażowania wykorzystuje bardziej efektywne formy raportowania (rysunek 1). 


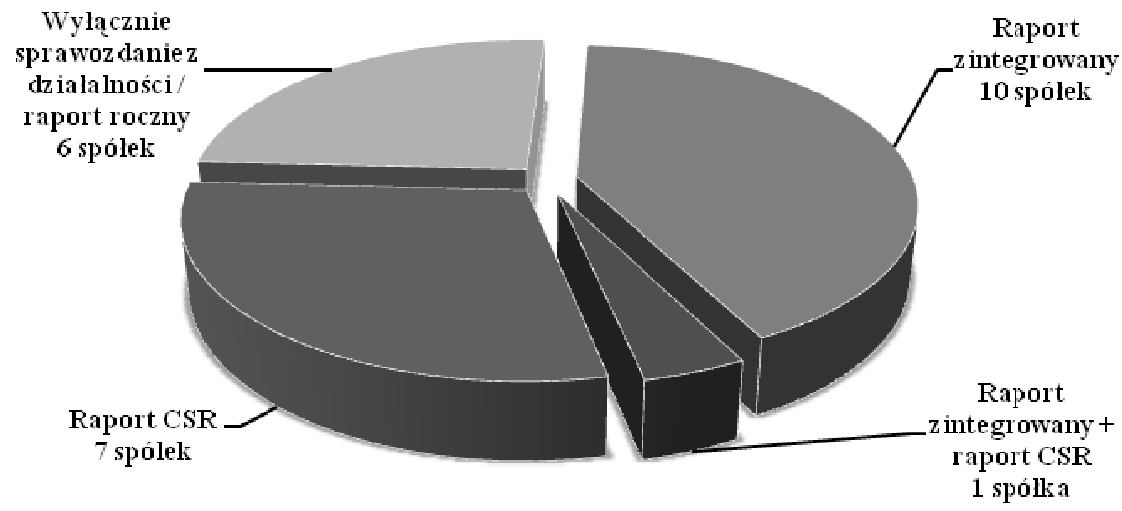

Rysunek 1. Społeczna odpowiedzialność biznesu w sprawozdawczości spółek wchodzących w skład indeksu RESPECT

Źródło: Opracowanie własne na podstawie raportów zamieszczonych na stronach internetowych badanych spółek (według stanu na dzień 09.10.2017 r.).

Preferowaną formę komunikowania społecznej odpowiedzialności stanowi raport zintegrowany, który jest sporządzany przez 11 spółek Indeksu RESPECT. Jest to nowa forma raportowania, która pozwala na pokazanie w jednym sprawozdaniu zależności pomiędzy strategią danego podmiotu, sposobem jego zarządzania, osiąganymi wynikami finansowymi oraz ekonomicznym, społecznym oraz środowiskowym aspektem funkcjonowania na rynku ${ }^{21}$. Znaczna części spółek wykorzystuje również raporty CSR, które jeszcze do niedawna stanowiły dominującą formę komunikowania działań z zakresu społecznej odpowiedzialności biznesu. W przeciwieństwie do raportów zintegrowanych trudno doszukać się w nich powiązań pomiędzy finansową oraz pozafinansową sferą działalności. Ukazują one bowiem wyłącznie aspekty związane ze społecznym i środowiskowym zaangażowaniem podmiotów rynkowych. Wśród spółek indeksu RESPECT jedna z nich, Grupa Azoty S.A., sporządza zarówno raport zintegrowany, jak i raport z zakresu CSR.

Spółki indeksu RESPECT charakteryzuje również dowolność pod względem częstotliwości sporządzania raportów społecznych. Przeważająca cześć badanych podmiotów stosuje roczny cykl raportowania danych z zakresu CSR. Wyróżnić można również raporty zawierające dane odnoszące się do dwóch, kolejno następujących po sobie okresów sprawozdawczych. Dowolność w zakresie raportowania społecznego skutkuje również brakiem wypracowanych procedur w zakresie terminowości przekazywania raportów. Większość dokumentów opublikowanych przez spółki Indeksu RESPECT zawiera informacje odnoszące się do działań podejmowanych w 2016 roku. Niemniej jednak znaleźć wśród nich można te, które dotyczą okresów wcześniejszych.

Coraz częściej tradycyjną wersję raportu dostępną w formacie PDF, uzupełnia bądź zastępuje wersja interaktywna umieszczana bezpośrednio na stronie internetowej.

${ }^{21}$ M. Marcinkowska, Kapital relacyjny banku. Ocena banku w kontekście relacji z interesariuszami, Wydawnictwo Uniwersytetu Łódzkiego, Łódź 2013, s. 45. 
Ułatwia to szybki dostęp do poszczególnych sekcji dokumentu, zwiększając przejrzystość prezentowanych danych. Pomimo znaczących różnic w zakresie i sposobie prezentacji danych, wszystkie spółki zamieszczają w raportach informacje odnoszące się do głównych obszarów społecznej odpowiedzialności biznesu. Dotyczą one zwłaszcza takich zagadnień, jak: etyka, relacje społeczne, oddziaływanie na środowisko naturalne, relacje z pracownikami, a także dialog z pozostałymi grupami interesariuszy.

\section{Podsumowanie i wnioski}

Wzrost znaczenia społecznej odpowiedzialności biznesu we wszystkich aspektach życia gospodarczego znajduje odzwierciedlenie $\mathrm{w}$ decyzjach podejmowanych przez inwestorów. Coraz cześciej w procesie inwestowania wolnych środków pieniężnych obok kryteriów ryzyko-zysk występują również inne o charakterze społecznym, środowiskowym oraz etycznym.

Istotną rolę w kształtowaniu pozycji spółki odpowiedzialnej społecznie odgrywa polityka komunikacyjna. Inwestorzy nie są w stanie zaspokoić swoich potrzeb informacyjnych wyłącznie na podstawie danych liczbowych zawartych w obligatoryjnie sporządzanych sprawozdaniach finansowych. Są oni zainteresowani również pozyskiwaniem informacji dotyczących ekonomicznego, społecznego, a także środowiskowego kontekstu funkcjonowania spółki na rynku.

Znajduje to przełożenie na politykę informacyjną spółek wchodzących w skład indeksu RESPECT. Komunikują one swoje działania w obszarze społecznej odpowiedzialności w sprawozdaniu z działalności. Ważną kwestią jest również to, że jedynie niewielka część spółek ogranicza się do tej obligatoryjnej formy komunikowania z szerokim gronem interesariuszy. Większość z nich publikuje odrębne raporty CSR, bądź też raporty zintegrowane. To właśnie raporty zintegrowane zawierają najbardziej kompleksowe informacje o dokonaniach danego podmiotu gospodarczego. Wynika to $\mathrm{z}$ faktu, iż $\mathrm{w}$ jednym dokumencie ujmują one informacje będące podstawą oceny wiarygodności zarówno finansowej, jak i niefinansowej.

Istotne jest również to, że w poszczególnych raportach znajdują się dane dotyczące wszystkich najważniejszych kwestii z zakresu społecznej odpowiedzialności biznesu. Co ważne są to nie tylko informacje opisowe, ale także określone wskaźniki pozwalające skwantyfikować społeczne i środowiskowe zaangażowanie przedsiębiorstw. Pomimo znaczących różnic z strukturze, objętości, a także zawartości publikowanych raportów umożliwia to dokonywanie pewnych porównań będących podstawą wyboru do portfela inwestycyjnego podmiotów wyróżniających się pozytywnym oddziaływaniem na społeczeństwo i środowisko.

\section{Literatura}

GPW, Lista spółek, https://www.gpw.pl/spolki [data dostępu: 09.10.2017].

Jedynak T., Kontrowersje wokót efektywności inwestycji społecznie odpowiedzialnych, „Zeszyty Naukowe Polskiego Towarzystwa Ekonomicznego", 2011, nr 11.

Jedynak T., Rozwój koncepcji inwestowania społecznie odpowiedzialnego w Polsce i na świecie, „Zeszyty Naukowe Uniwersytetu Ekonomicznego w Krakowie”, 2011, nr 875.

Maćkowiak E., Polityka rachunkowości a kierunki zmian raportowania w przedsiębiorstwach, „Studia Ekonomiczne”, 2014, nr 201. 
Marcinkowska M., Kapitat relacyjny banku. Ocena banku $w$ kontekście relacji z interesariuszami, Wydawnictwo Uniwersytetu Łódzkiego, Łódź 2013.

Mazurczak A., Raportowanie społecznej odpowiedzialności biznesu jako nowy element raportowania biznesowego [w:] B. Micherda (red.), Kierunki ewolucji sprawozdawczości i rewizji finansowej, Wydawnictwo Difin, Warszawa 2012.

Mendryk I., Budowanie relacji z otoczeniem jako kompetencja organizacji, „Annales Universitatis Mariae Curie-Sklodowska. Sectio H. Oeconomia”, 2008, Vol. XLII, 10.

Ostaszewski J. (red.), Finanse, Wydawnictwo Difin, Warszawa 2013.

RESPECT Index, Opis projektu, http://www.odpowiedzialni.gpw.pl/opis_projektu [data dostępu: 01.10.2017].

Rok B., Odpowiedzialny biznes w nieodpowiedzialnym świecie, Akademia Rozwoju Filantropii w Polsce - Forum Odpowiedzialnego Biznesu, Warszawa 2004.

Rudnicka A., Komunikowanie o społecznej odpowiedzialności między przedsiębiorstwem a interesariuszami [w:] Z. Pisz, M. Rojek-Nowosielska (red.), Społeczna odpowiedzialność organizacji. Metodyka, narzędzia, ocena, Wydawnictwo Uniwersytetu Ekonomicznego we Wrocławiu, Wrocław 2011.

Szot- Gabryś T., Społecznie odpowiedzialne inwestowanie a społecznie odpowiedzialne inwestycje [w:] J. Ostaszewski (red.), O nowy ład finansowy w Polsce. Rekomendacje dla animatorów życia gospodarczego, Szkoła Główna Handlowa w Warszawie, Warszawa 2015.

Ustawa z dnia 29 września 1994 r. o rachunkowości, Dz. U. 1994 Nr 121 poz. 591 ze zm.

Zasuwa G., Spoleczna odpowiedzialność jako perspektywiczny obszar w sprawozdawczości przedsiębiorstw [w:] D.A. Mikulska, Polityka rachunkowości jednostki a jakość sprawozdania finansowego. Wybrane aspekty, Wydawnictwo KUL, Lublin 2012.

Żychlewicz M., Społeczna odpowiedzialność biznesu jako strategia prowadzenia działalności polskich przedsiębiorstw, „Współczesne problemy ekonomiczne”, 2015, $\mathrm{nr} 11$.

\section{Summary}

The effectiveness of the enterprise's current activity and achieving its development objectives is inextricably linked to the raising the adequate amount of capital. Finding investors increasingly is determined not only by building financial credibility. During the process of selecting the portfolio, many investors complements traditional financial criteria by additional set of corporate social responsibility rules. The development of socially responsible investing causes the interest in increased activity of enterprises in providing information not only in the financial but also in the social and environmental perspective.

The aim of the article is to present the importance of communication of CSR activities in the process of socially responsible investing. The starting point for the implementation of a such formulated purpose was to present theoretical basis of the concept of socially responsible investing as well as the issues related to CSR communication, which may support this type of investing. Next, the paper focuses on the analysis of approach to communication of socially responsible activities by companies included in RESPECT Index.

Results of the research lead to the conclusion that companies included in the RESPECT Index are aware of the importance of disclosing information concerning corporate social responsibility. Most of them are not limited to communicating economic, social and environmental issues within activity reports, but in addition, publish separate CSR reports or integrated reports which present in one document both financial and non-financial aspects of business activity.

Keywords: corporate social responsibility, socially responsible investing, communication of socially responsible activities 
Informacje o autorach:

dr hab. Grażyna Michalczuk, prof. UwB

Uniwersytet w Białymstoku

Wydział Ekonomii i Zarządzania

Katedra Finansów, Rachunkowości i Informatyki

ul. Warszawska 63, 15-062 Białystok

e-mail: g.michalczuk@uwb.edu.pl

mgr Urszula Konarzewska

Uniwersytet w Białymstoku

Wydział Ekonomii i Zarządzania

Katedra Finansów, Rachunkowości i Informatyki

ul. Warszawska 63, 15-062 Białystok

e-mail: u.konarzewska@uwb.edu.pl 